\title{
MEMORY TRANSMISSION IN DORA BRUDER NOVEL: A POST-MEMORY ANALYSIS
}

\author{
Fauzan Hanif, Wening Udasmoro, Wulan Tri Astuti
}

\author{
udasmoro@ugm.ac.id \\ French Literature Study Program, Universitas Gadjah Mada \\ Sleman, DI Yogyakarta, Indonesia
}

\begin{abstract}
Traumatic events such as the Holocaust transcend through generations. Hirsch strengthens this argument by saying that post-memory is a study of the structure of intergenerational and trans-generational memory transmission in the form of traumatic knowledge and experiences. This study raises the meaning of memory transmission in the Dora Bruder novel by Patrick Modiano. The method used in this article is the content analysis of the story. The data are collected form of sentences that describe the meaningful forms of memory transmission. There are three interpretations from the results of memory transmission. They are the narrator's interpretation of a location as signifiers of the incommensurability of return, the narrator's interpretation as an agent and actor of allo-identification, and the emergence of a desire to reject the act of forgetting. Analysis using post-memory illustrates that the generation of heirs to the traumatic memories inherits various challenged and debated questions, intending to expose and retell that story to the public.
\end{abstract}

Keywords: post-memory, memory transmission, the meaning of memory transmission

\section{INTRODUCTION}

Post-generation always believes possibilities may explain the meeting with 'those who have preceded' in each of its steps. A short and condensed quote from Modiano, a post-generation writer, reflects on this concept that we can find in his novel, Dora Bruder (1999):

Peut-être-mais j'en suis sûr-s'est-elle promenée là, dans cette zone qui m'évoque les rendez-vous d'amour secrets, les pauvres bonheurs perdus (Modiano, 1999, p. 35).

Perhaps - but I am pretty sure - he used to walk there, in a zone that evokes a sense of hidden love encounters, also about lost gloomy bliss.

As a post-generation writer, Modiano tries to share the possibility that they, the generation who have preceded him, are still left there in the form of «les rendez-vous d'amour secrets et les pauvres bonheurs perdus» or secret love dating and lost imperfect happiness. The occurrence of the intragenerational memory transmission process does not simply accommodate the narrator's mediation with the figure of 'elle' or Dora Bruder (Fernanda, 2017, pp. 83-84). By placing the girl's projection between the hidden love meeting space and the lost happiness, the narrator's projection, which is a metaphor for the disappearance of an entity, affirms how much burden a post-generation receives after going through the memory transmission process (Hirsch, 2012, p. 212).

Therefore, though in the form of a novel, a piece of Dora Bruder's novel takes part to justify that fiction literacy today holds an essential role in passing down memory concerning what happened to Holocaust survivors' generation (Damamme-Gilbert, 2015). In his work of fiction, Modiano's words also confirm the words of Susan Sontag (in Hirsch, 2008), who embed the term 'pain of others' for post-generationists due to the burden of 'pain' they experience. Postgeneration carries, even feels, this "pain" 
throughout their life (Fernanda, 2017, p. 85). The 'pain' does not come from themselves, but from the generation living before them, like their parents and their grandparents' generation. Eva Hoffman also emphasized that the knowledge transmitted indirectly will continue to overshadow the generations after it (in Hirsch, 2008).

In the structure of the novel's memory transmission, post-memory elements and the process of their appearance are created through the main character of a postgeneration. Interaction with various objects, documents, and locations to the intimacy of the character's memory itself can lead to the investment in every imagination (Cahyasari, 2017, p. 70), projections, and creations regarding memories of a period that has preceded him, namely the time before he was born. The memory indicates memory transactions between himself as postgeneration and the generation who experienced the Holocaust (Intan, 2017). However, what happens after the memory transmission process also needs special attention. Aleida Assmann (in Hirsch, 2012) states that the role of objects and places is a trigger for the emergence of memory in the post-generation body (body or sense memory). It is not their personal experience toward an object or place for post-generation, but the experience and pain from the previous generation that motivates them to interpret, even trace back the traces of past that are left and remain. Assmann continues that objects or places reflect the past life, remain in postgeneration life and memory. Life is immersed and recorded; therefore, it needs to be explored and extracted by post-generation as the meaning reflections of whatever occurs when they are not present in the world.

Therefore, successively, the meaningful forms of memory transmission manifest themselves through the main narrator in the Dora Bruder's novel. The memory transmission process that occurred triggers the transformation of location into signifiers of the incommensurability of return, later on, the allo-identification process in the narrator's selfpositioning toward past figures, which is responsible for the emergence of a desire to reject the act of forgetting concerning everything that happened during the Holocaust.

\section{METHOD}

The focus in this research is postmemory transmission meaning by postgeneration. The steps of this article are divided into the following stages: collecting data, categorizing data and analyzing data. This research data are in the form of sentences that describe forms of post-memory transmission meaning. In the collecting data stage, the researchers carry out the heuristic reading of the material object previously. After that, it is continued with the repeated hermeneutic reading of the Dora Bruder novel. Later on, the researcher assembled the text structure by determining a series of stories (sequences) according to the structure of the narrative analysis (Udasmoro, 2012).

It should be noted that the post-memory narratives that emerge do not always stick together like a dough, but they are fragmented separately and randomly. Frost (2010) explains that among these fragments, three main elements indicate a great discourse concerning post-memory in it, namely: (1) fictional element, (2) familial element, and (3) historical element (historical). After the sequences are collected, the primary sequences referring to the narrative regarding the meaning of post-memory transmission are determined. The data that has been collected is afterward categorized by being included in the table. Data differentiation in tables is carried out using several indicators, mainly the interpretation of affiliate memory transmissions. The next step is to analyze the data that has been grouped according to research needs (Udasmoro, 2018). Data analysis in this study uses post-memory theory to dissect and interpret the results of the transmission process in post-generation.

It should be noted that narrative and analysis of absence in various forms such as silence, absence, and emptiness are always present and dialectical rather than presence. Frost (2010) calls it a 'memory and narrative emptiness.' Absence can even become a focal point in the discussion of post-memory works (Kumalasari, 2016a, 2016b).

\section{FINDINGS AND DISCUSSION}

Signifiers of the Incommensurability of Return as Meaning upon a Sense of Emptiness 
Signifiers of the incommensurability of return or markers of incommensurability of return trip behavior are the concepts found by Hirsch (2012, p. 208) after analyzing Ghassan Kanafani's "The Return to Haifa." These phrases can be interpreted that an object that disappears can turn into a unit to measure the time passed with the lives of its people. This transformation of object or place into a marker of incommensurability does not solely happen by accident, but through the characters' introspection investigating the reasons behind the object's disappearance or place.

In Dora Bruder's novel, a similar thing is also reflected. More specifically, the manifestation of this incommensurability marker is the narrator's conception of meaning after receiving a memory transmission through the visit to a location that they believe is related to the existence of Dora Bruder. Some areas such as Clignancourt, central Paris, and the Tourelles barracks convey a memorable impression of a feeling of emptiness, naughtiness, and neglect to the narrator. These areas, either directly or indirectly, provide a space for the intersection of familial (Clignancourt and Paris) or affilial (Clignancourt, Paris, and Tourelles' barracks) within the narrator.

However, when exploring locations that do not have any affiliate or familial relationship with them, the narrator states that they also feel the presence of emptiness. For example, the following quote explains that the narrator was in a district where they did not specify its name at the age of twenty. There, they feel a similar impression like they have felt elsewhere in connection with the disappearance of Dora's brother, the Tourelles barracks:

$\grave{A}$ vingt ans, dans un quartier de Paris, je me souviens d'avoir éprouvé cette même sensation de vide que devant le mur des Tourelles, sans savoir quelle en était la vraie raison (Modiano, 1999, p. 132).

When I was twenty, in a district in Paris, I remember experiencing the same sensation of naughtiness that I felt in front of the walls of the Tourelles barracks, without knowing the real reason.
The sensation the narrator feels is the sensation of emptiness when they stand in front of the wall surrounding the Tourelles barracks. It should be underlined here that the "emptiness" they feel in the district is connected to one specific location in which they experienced it when the narrator was twenty years old. Therefore, it means that they had felt the emptiness long before the search for Dora Bruder before they found and positioned themselves before the walls of Tourelles barracks. Thus, it can be said that it was the feeling of emptiness they felt in the Tourelles barracks which led them to flashback to a similar feeling they had felt, at the age of twenty, in a district of Paris.

Furthermore, Tourelles barracks had caused the narrator to recall the similar feeling of emptiness that manifests in a different place and time, without ever knowing the reason behind that feeling. Since getting the feeling of emptiness for the first time, the narrator unconsciously keeps and questions it until he visits the Tourelles barracks. The impression of emptiness buries them along with the unknown cause of these feelings.

The narrator's attained emanations while in Tourelles barracks lead them to recall similar emotional upheavals in a district in Paris. This event indicates that locations that appear to be disconnected from one another can "bind" an individual. In this case, postgeneration experiences a jolting feeling which manifests as a sensation of 'emptiness.' The interconnectivity of the spatial and temporal dimensions is created by emphasizing the postgenerational feeling of the areas he visited and creating a connection between them through these feelings.

On the other hand, the narrator's flashback still continues. After visiting a warehouse to meet a thrift dealer, he went out and down the Jardins-Saint-Paul road toward the Seine. The narrator begins to describe in sufficient detail the various buildings he saw:

En le quittant, j'ai suivi la rue des JardinsSaint-Paul, vers la Seine. Tous les immeubles de la rue, côté des numéros impairs, avaient été rasés peu de temps auparavant. Et d'autres immeubles derrière eux. À leur emplacement, il ne restait qu'un terrain vague, lui-même cerné par des pans d'immeubles à moitié 
détruits. On distinguait encore, sur les murs à ciel ouvert, les papiers peints des anciennes chambres, les traces des conduits de cheminée. On aurait dit que le quartier avait subi un bombardement, et l'impression de vide était encore plus forte à cause de l'échappée de cette rue vers la Seine (Modiano, 1999, p. 133).

Getting out of there, I followed the Jardins-Saint-Paul road towards the Seine. The entire building on that street, the odd-numbered side, had been obliterated shortly before. Moreover, the other buildings behind it also experienced the same thing. Instead, all that was left was empty land surrounded by half-destroyed buildings. On the walls that looked up towards the sky, you could still see the wallpaper from the former room and the traces of the fireplace. We can assume that the territory had been bombed, and the impression of emptiness was even more potent due to this escape route to the Seine.

Based on his observations, the narrator showed his sensitivity to the loss of human intimacy within the family circle by including "wallpaper from former rooms" and "fireplace trail." Previously, these objects were the most intense interaction space with the closest people. For example, in a comic entitled First Maus (Spiegelman in Hirsch, 2012, pp. 29-30), Poppa was told to perform a "bedtime story" to his child in the child's bedroom. It suggests the relationship between father-son intimacies in the familial realm that is intertwined in the bedroom. Therefore, although they do not entirely disappear, the remaining traces can echo the narrator's 'emptiness.'

The story goes back to the actual period, when the narrator visits the district, also via the Jardins-Saint-Paul road. Recalling their meeting with the second-hand dealer, they discover that the buildings used to occupy several points on that part of the road are no longer there:

Je pensais à cela, cet automne, en marchant de nouveau dans le quartier de la rue des Jardins-Saint-Paul. Le dépôt et son rideau de fer rouillé n'existent plus et les immeubles voisins ont été restaurés (Modiano, 1999, p. 135).

I thought about it, that spring, walking back down the district and the JardinsSaint-Paul Street. The warehouse and its iron curtains are no longer there, and the neighboring buildings have been restored.

The intended warehouse is the one owned by a second-hand goods salesman the narrator had previously met. They cannot find the place again, and other buildings in the vicinity have also been restored. However, after years leaving the region, when the narrator returns there, the emptiness they once felt begins to buzz again. However, a significant difference appears here when the narrator finally can indicate the cause of the appearance of this impression so far:

De nouveau je ressentais un vide. Et je comprenais pourquoi. La plupart des immeubles $d u$ quartier avaient été détruits après la guerre, d'une manière méthodique, selon une décision administrative. Et l'on avait même donné un nom et un chiffre à cette zone qu'il fallait raser: l'îlot 16 (Modiano, 1999, pp. 135-136).

Again I feel emptiness. Moreover, I understand it now. Most of the buildings in this district were destroyed after the war, in methodical ways based on administrative decisions. They even gave the zone a name and number to clear: Block 16.

The narrator finally concludes that the impression of emptiness overtaking them appeared because of the destruction intended to flatten the area so that the district development could be carried out. Therefore, the destroyed building does mean a 'devastation' of the material and a stage of 'rearrangement' of the city's parts that have been damaged during the war. The new name "Block 16" (l'îlot 16) further confirms the action to rearrange the city based on the formal documentation.

However, the attempt to physically "revive" this part of the city regenerates their 
sense of emptiness for the narrator. Furthermore, the whole "cleansing" applied to the worn and damaged components that make up the face of the Jardins-Saint-Paul neighborhood's past is even the reason and justification for the impressions that have so far hit it. Their understanding appeared when they realized that what was left behind and abandoned produced losses. All the leftovers would not be replaced due to the areal clearance leading to the reorganization of the city.

For the narrator, new buildings and places that replace the old ones are the big problems. The presence of new buildings implies the act of "forgetting," because of the narrator's "delay" in recognizing the context of the environment. They came "late" due to the events of war and bombing before they were born to the world. Although the narrator can trace it through a collection of photographs depicting the circumstances surrounding Jardins-Saint-Paul during their peacetime (Modiano, 1999, p. 136), the narrator will never be able to reach these times. It was this knowledge that they wanted to reveal, what they wanted to know, and what they wanted to protect. Quoting Hirsch (Hirsch, 2012, p. 160), their position as children of the generation who experienced traumatic situations made them imagining the events and the feelings they experienced (Udasmoro, 2014, pp. 74-75). The child in this case, the narrator, will always have a hard time because he does not exist and will never be there. According to the narrator, this method of cleaning and rebuilding takes away the things they want to know. His symbolic practice implies the 'memory killing' of the construction:

Les façades étaient rectilignes, les fenêtres carrées, le béton de la couleur de l'amnésie. Les lampadaires projetaient une lumière froide. De temps en temps, un banc, un square, des arbres, accessoires d'un décor, feuilles artificielles (Modiano, 1999, p. 136).

The face of the building is square, the windows are rectangular, and amnesia is the color of the concrete. Street lamps provide an incredible glow. From time to time, benches, parks, trees, decorative accessories, and artificial leaves.
In the above quotation, the narrator identifies the physical characteristics of these new buildings while at the same time trying to link these physical characteristics to the feeling of being 'empty.' By pointing to rebuilding as the root cause of the emptiness they feel as post-generation, the narrator finally asserts that the concrete that constructs the buildings has a color equivalent to amnesia or memory loss. Furthermore, the narrator also observes the rearranged natural conditions, explicitly mentioning "feuilles artificielles" or "artificial leaves" at the end of the sentence.

The choice of the words "amnesia" and "artificial" reflects the narrator's assumption that the combination between the components and the novelty elements involved in them is just an attempt to forget pieces of history that should be exposed (Udasmoro, 2014, p. 54). This assumption stems from the narrator's curiosity as a post-generationist who had never existed before "amnesia" was presented in the form of city reconstruction. These "amnesia" events are expressed in the days before the city was destroyed when the traces of wallpaper and fireplace imprints that he found still had the function of reconciling the people who lived around Jardins-Saint-Paul Street. People at Dora's age had lived there before the police hunted them down, as explained below:

Les lambeaux de papiers peints quej'avais vus encore il y a trente ans rue des JardinsSaint-Paul, c'étaient les traces de chambres où l'on avait habité jadis - les chambres où vivaient ceux et celles de l'âge de Dora que les policiers étaient venus chercher un jour de juillet 1942 (Modiano, 1999, p. 136).

The scraps of wallpaper I saw thirty years ago on Jardins-Saint-Paul Street were traces of their former room - the ones where people at Dora's age lived until the police came looking for them, one day in July 1942.

Between places that do not appear to have any connection, there is still something capable of declaring a relationship-building line between them. The feelings formed in the narrator are the trajectories that unite these 
places. The echo of similar "emptiness" in two different places proves these feelings. Through the above quotation, the narrator increasingly shows and pastes the connection lines. By representing the narrator's motive, looking for traces of a girl named Dora Bruder, they also juxtapose the position of 'those' which the narrator believes once stayed and lived along the Jardins-Saint-Paul road.

The narrator concludes their impression of the construction of new buildings and the total remodeling of the neighborhood's streets by saying:

La liste de leurs noms s'accompagne toujours des mêmes noms de rues. Et les numéros des immeubles et les noms des rues ne correspondent plus à rien (Modiano, 1999, p. 36)

Their list of names is always followed by the names of the street in which they live-furthermore, the building numbers and street names that are now no longer related to anything.

The above quote is the final part of the whole journey, searching for answers to the impressions that come to the narrator. It shows that the narrator did not make any effort to reveal what caused his impression all this time. The city's construction and rearrangement refer to the process of forgetting those who once lived and breathed the Jardins-Saint-Paul neighborhood's air and its surroundings.

The narrator will never know if there is no construction going on. They will continue to wonder about the actual form of the emptiness they feel after the new buildings were built and the streets were renovated again. Later, the narrator realizes one thing, "they" (ceux et celles) who had lived there were tragically buried along with the tactical-systematicstrategic destruction process. More specifically, for the narrator, what also disappears are the memories of 'them,' along with the number of buildings and street names that have been changed to revitalize the shape of the city. The whole novelty, which administratively plays a role in reconstructing and tidying up the remnants of the Second World War, is interpreted by the narrator as something that is 'no longer related to anything' (...ne correspondent plus à rien).
Everything has been cut off since the establishment of new urban planning. "Like being cut by a knife suddenly," quotes Kanafani (in Hirsch, 2012, p. 207) when explaining how the past overcomes the present. In the end, the narrator begins to realize that in this interrupted period, there are people who have the same fate as Dora Bruder - living in several rooms, under one roof of the same building, later being taken all their lives by the police on duty who were caught them, one day in July 1942.

Through this reflection, it can be concluded that all the physical elements of the Jardins-Saint-Paul that have been destroyed and disappeared. The streets, buildings, and building numbers, to the 'ex-bedroom wall paper' and 'the fireplace trail,' have been transformed into signifiers of the incommensurability of return. The reflection that the narrator shows to the disappearance of the object and place makes the process of transformation possible. The transmission of affiliate memory between the narrators through the location in the Tourelles barracks can foster a deep meaning of the constellation of impressions that constantly buzz wherever he is later. He saw the existence of 'nothingness' (sensation de vide). According to Hirsch (Hirsch, 2012, p. 247), emptiness, along with silence and absence, is precisely what is always present and becomes the center of postmemory manifested in the narrator of Dora Bruder.

\section{Narrator as Allo-identification Agent and Actor}

Allo-identification or "identification with" is a form of identification performed by post-generation toward the experiences of the survivors' generation. Those experiences, which happen historically differently, can be narrated and integrated into the present using stories and pictures (Szép, 2014, p. 22). The result of allo-identification opens the possibility of second-generation memories based on the identification that is mediated in a more conscious way (Kumalasari, 2016a, p. 62). In the process, a heteropathic process of identification applies. It is a way to connect "what is not-me" ("not-me") with "I" ("me") without internalizing the 'not-me' into the subject itself. Through embedded firstgeneration discursive memories, subjects can 
participate in the desires, struggles, and sufferings of others without actually being 'hurt.' Therefore, post-memory is a form of heteropathic memory in which the self and other are connected through familial or group relations. The novel writer's position in the extra-familial space makes him an alloidentification agent (post-memory affiliate) and a medium for historical breaking (historical withholding). On the other hand, the reader eventually transforms into, to quote Hirsch (2012, p. 97), "a member of a generation as well as an eye witness of a particular historical moment."

Through the novel Dora Bruder, the narrator's findings on letters that manifest as points of memory, or 'memory dots,' the narrator begins the process of identifying his first-generation experiences (O'Byrne, 2019: $3)$. These "memory dots" are connected with the attempt to transmit remnants of the past to anyone in the present. The letters were written and explicitly addressed to the police and had the same tone: requests for information about the family members.

Mais il reste, dans les archives, des centaines et des centaines de lettres adressées au préfet de police de l'époque et auxquelles il n'a jamais répondu. Elles ont été là pendant plus d'un demi-siècle, comme des sacs de courrier oubliés au fond du hangar d'une lointaine étape de l'Aéropostale.... (Modiano, 1999, p. 84) ...

«Monsieur le Préfet

J'ai l'honneur d'attirer votre attention sur ma demande. Il s'agit de mon neveu Albert Graudens, de nationalité française, à l'âge de 16 ans, qui a été interné...»

«Monsieur le directeur du service des juifs Je sollicite de votre haute bienveillance la libération du camp de Drancy de ma fille, Nelly Trautmann...»

"Monsieur le Préfet de Police

Je me permets de solliciter de vous une faveur en l'honneur de mon mari, Zelik Pergricht, me permettant de savoir de ses nouvelles et quelques renseignements... » ... (Modiano, 1999, p. 84)

However, hundreds of letters were addressed to the police officers at that time, all of which have never been replied to in the pile of files. The letters have been there for more than half a century, looking like sacks of forgotten letters lying under a hangar on Aeropostale's farthest platform. ...

\section{"Mr. Chief}

It is an honor for me to ask your attention regarding my application. My nephew, Albert Graudens, a French citizen, is 16 years old in exile..."

"Mr. Director of Jewish Affairs

I plead with all your kindness, liberation from Drancy camp for my daughter, Nelly Trautmann...”

"Mr. Chief of Police

I ask for your help regarding, with respect, my husband, Zelik Pergricht. Allow me to know the latest news and some information..."...

In the familial sphere, these letters give a face to the curiosity of the family left behind. When the letter is included in the story, the narrator dramatically activates kinship ties - which are forced to break — as a space for affiliative memory (Laborde, 2019, p. 123). He invites readers to engage in the 'act of remembering culturally,' as he explained right before embedding the letters into his script:

Aujourd'hui nous pouvons les lire. Ceux à qui elles étaient adressées n'ont pas voulu en tenir compte et maintenant, c'est nous, qui n'étions pas encore nés à cette époque, qui en sommes les destinataires et les gardiens ... (Modiano, 1999, p. 84).

Today we can read it. However, then, the people they were talking to did not want to pay attention to it, and now, we, who were not born at that time, are the recipients and the guardians...

The narrator realizes that it has been ages since the letters were sent but only to be hoarded and ignored. The letters contained familial ties from the writing process to the delivery; they represented an attempt to mediate the gap created by losing a related family member. Finding the pile of letters, the 
narrator logically positions themselves in the beginning as the 'reader' and 'listener' of these tragically never conveyed messages (Laborde, 2019 , p. 126). The next thing that needs to be reaffirmed on the narrator's position as the 'reader' and 'listener' of these messages reflects the presence of the extra-familial subject represented by them. Hence, when the narrator took over the letters-more than half a century later-and positioned themselves as actual 'memory dots,' the narrator was instrumental in transmitting these kinship ties into the public sphere.

In the case of the narrator Dora Bruder, they did not immediately identify victim writers, as Jeffrey Wolin did in his work (in Hirsch, 2012, p. 93). It does not carry out direct analysis and identification of each letter or individual sender but puts them one by one as a collection of different 'dots' but has the same anxiety. This collection of dots is interpreted as a "desire for longing. Although it is not physically visible, what passed onto the narrator is currently in the position of "receiver and guardian" of this "desire." The interpretation results in a desire to know the fate of this closest family member identified by the narrator when reading the letters.

At the same time, the narrator does not position themselves as a "reader, receiver, and guardian"; they choose to use the plural firstperson pronoun "nous" (we), therefore as to include themselves with the public, in this case, the reader, who was neither present during the Holocaust period to play a role in maintaining the "desire for longing" which was manifested in these letters (Udasmoro, 2014, p. 54). Cooke (2004, p. 141) underlines that the reader becomes a partner for the narrator in venturing grief and archiving the message even the "desire." Therefore, the narrator practices horizontal intergenerational identification of fellow post-generations, where this form of affiliative identification is itself an extension of the broken domestic relationship (Hirsch, 2012, p. 36). He becomes an identifier when he finds out that there is a "desire for longing" in the familial sphere that is hidden in each letter, as well as being a liaison or "agent" of the identification process by transmitting it to the public through an explicit invitation which he writes in the script (Wolf, 2019, pp. 79-80). The narrator invites and emphasizes that everyone who was not present at that time now serves as the "receiver and guardian" of this "desire." The narrator guides the public to position himself as "a member of a generation as well as an eye witness of certain historical moments" in the act of cultural remembrance.

\section{Reject to the Act of Forgetting}

The following sub-chapter discusses a continuation of the narrator's reflection as an agent and an allo-identification actor so that this section is closely related to the previous section. The manifestation of letters substantively contains "longing desire" and their transmission to the public so that they become "recipients and guardians" of this desire. It indicates the narrator's desire to protect the past message to live in the present. Undeniably, in the future, the narrator's understanding of the condition of the letters is neglected or even forgotten altogether and becomes, to quote Cooke (2004, p. 141), "dead letters" if they are not "recorded" in the storytelling process. Moreover, before finding the letters, the narrator failed to find the transcripts of the detainees' interrogations because they had been destroyed (Modiano, 1999, p. 84).

Nevertheless, the transcript reveals the names of each detainee, and the police who arrest the perpetrators were listed. Moreover, they also disappeared along with the destruction of the transcript. Even by saying "on ne connaitra jamais les noms des" agents capteurs" here, the narrator emphasizes his ignorance of these arrest officers. Therefore, there is a possibility that the names and documents of victims they had mentioned in their story, where they also want to trace and know, contain not only an artifact per se but also the stories of the traumatic events from the perpetrator's perspective (Baackmann, 2017, p. 169).

The narrator's unconsciousness made him develop allegations against anyone deemed to have prevented them from finding any documents or files related to their search. This sense of allegations appears when the narrator tries to request a photocopy of Dora Bruder's birth certificate at the Community Service Center (service de l'état civil) in February 1996 (Modiano, 1999, p. 15). Unfortunately, the duty officer was unable to provide the file because the narrator did not 
have any family ties with Dora Bruder. Not long after they were informed of this, an assumption, although it only appeared for a moment, flashed through his mind:

\begin{abstract}
Un moment, j'ai pensé qu'il était l'une de ces sentinelles de l'oubli chargées de garder un secret honteux, et d'interdire à ceux qui le voulaient de retrouver la moindre trace de l'existence de quelqu'un (Modiano, 1999, p. 16).
\end{abstract}

For a moment, I thought he was one of the guardians of forgetfulness, being tasked with keeping shameful secrets and forbidding those who wanted to find traces of someone's existence.

The duty officer's refusal was logical and had a firm basis. The narrator does not have familial closeness to the person they are looking for. Under the conditions stated on the blank request for a birth certificate, people outside the line of kinship cannot be given a photocopy of the birth certificate. Therefore, it can be said that both the narrator and the duty officer acted honestly by not deceiving either party. However, the flash of impression that crosses the narrator shows suspicion of the guard. The narrator considered that the guard could not get Dora Bruder's birth certificate file because "un secret honteux" is hidden, and the officer was charged with keeping it. The narrator bluntly identifies the interlocutor as l'une des sentinelles de l'oubli, "guardian of forgetfulness," which they are "forbidden to say anything to anyone who wants to discover traces of someone's existence."

The narrator's correlation between traces of someone's existence, which Dora Bruder represents as a "shameful secret," reveals the narrator's conception of the past. One way to find out was to access authentic documents (Orlando, 2016, pp. 93-94). Referring to the words of Hirsch (2012, p. 41), that, for post-generation, the past lies in various objects. One of which is a document that comes from the past which can still be reached, although that does not mean it can be easily achieved because, according to the narrator, there is a dividing wall called Sentinelles de L'oubli which emphasizes a divide between the present (represented by the narrator) and the past (represented by
Dora Bruder). According to Cooke (2004, p. 136), the meaning of sentinelles de l'oubli is not just a barrier; more than that, they serve to 'destroy' access to the past. "Destruction" is not interpreted here as a form of literal destruction of physical archives but through the act of silencing by not giving any information to the narrator - leaving it lying in the present without being accessible to anyone. Therefore, Greenberg (2007, p. 353) explains that the narrator is trying to reject the "full erasure" which is manifested by the existence of cultural forces in the form of these sentinelles de l'oubli. $\mathrm{He}$ rejects the intentional "forgetting" presence; 'Forget' who is under tight guard by a group of people; 'forgetfulness' destroys access to a time in which there is a "shameful secret." Therefore, by including various documents that have been transformed into public archives such as newspaper rubric pieces (Modiano, 1999, p. 6), Dora Bruder's birth certificate, and so on, the narrator is trying to 'carry' - even to the extreme it can be described as 'reviving' - back in the past.

Unfortunately, however, the past is a time filled with traumatic events worth tracing, discovering, disclosing, and retelling. These kinds and forms of documents saved the lives of the detained and "punished" individuals for violations they never committed. Therefore, the whole process of mass judgment against "guilty" people can be called un secret honteux or secret shame by placing the "lives" of people whose stories are housed in authentic documents that can still be achieved today into the storytelling. The narrator has echoed his resistance to the actions of "hiding," "leaving," "forgetting." Like what he said before, he, with us (nous) that addresses readers, is the "receiver and guardian" of those heartbreaking stories because "we" here, as Cooke (Cooke, 2004, p. 142) points out, have been constructed as a building of solidarity against a common enemy called 'to forget.'

\section{CONCLUSION}

A further problem worth investigating after the memory transmission is the understanding of the meaning of each transmission process that is passed on to the narrator. Generally, the analysis of the narrator's form of meaning is drawn from the transmission of affiliate memory that dominates the work. Three forms of meaning 
have been thoroughly analyzed, which are the narrator's self-meaning of the location that is transformed into signifiers of the incommensurability of return, later the narrator's self-meaning as an agent and actor of allo-identification, and closes with the occurrence of a desire to reject the act of forgetting.

The results of this article prove the meaning of memory transmission in Dora Bruder's novel as a post-memory work. Patrick
Modiano's works are access to post-memory, particularly those who affiliated with the events of the Holocaust. Analysis from a postmemory point of view illustrates that in the generation of heirs to memories of traumatic events such as the Holocaust, various problems are questioned and debated, exposed, and retold to the public. No matter how long time requires, post-generation will still look for the remaining pieces from the past that carry over to the present.

\section{REFERENCES}

Baackmann, S. (2017). Lore, or the Implicated Witness: Rachel Seiffert's Postmemory Work. In M. J. Martínez-Alfaro \& S. Pellicer-Ortín (Eds.), Memory Frictions in Contemporary Literature (pp. 165-186). Cham: Springer International Publishing. https://doi.org/10.1007/978-3-31961759-6_9

Cahyasari, I. (2017). Kekuatan Memori dan (Ketidak)Mungkinan Pengampunan dalam Novel Hanauzumi Karya Jun'ichi Watanabe. Poetika: Jurnal Ilmu Sastra, 5(2), 68-81. https://doi.org/10.22146/poetika.v5i2.30972

Cooke, D. (2004). Hollow Imprints. Journal of Modern Jewish Studies, 3(2), 131-145. https://doi.org/10.1080/1472588042000225802

Damamme-Gilbert, B. (2015). The Question of Genre in Holocaust Narrative: The Case of Patrick Modiano's Dora Bruder. In G. Dowd \& N. Rulyova (Eds.), Genre Trajectories: Identifying, Mapping, Projecting (pp. 45-65). London: Palgrave Macmillan UK. https://doi.org/10.1057/9781137505484_4

Fernanda, A. (2017). Transmisi Memori dan Trauma dalam Mother Land Karya Dmetri Kakmi: Kajian Postmemory. Poetika: Jurnal Ilmu Sastra, 5(2), 82-95. https://doi.org/10.22146/poetika.v5i2.30937

Frost, H. D. (2010). Recent Literature of the Holocaust: Negotiations with (post)Memory and the Archive (Ph.D. dissertation). University of Witwatersrand, Johannesburg.

Greenberg, J. (2007). Trauma and Transmission: Echoes of the Missing Past in Dora Bruder. Studies in 20th \& 21st Century Literature, 31(2). https://doi.org/10.4148/2334-4415.1657

Hirsch, M. (2008). The Generation of Postmemory. Poetics Today, 29(1), 103-128. https://doi.org/10.1215/03335372-2007-019

Hirsch, M. (2012). The Generation of Postmemory: Writing and Visual Culture After the Holocaust. New York: Columbia University Press.

Intan, T. (2017). Novel Charlotte Karya David Foenkinos: Sebuah Narasi Tentang Diskriminasi, Rasisme, dan Holocaust. Poetika: Jurnal Ilmu Sastra, 5(2), 96-108. https://doi.org/10.22146/poetika.v5i2.28979

Kumalasari, I. (2016a). Membaca Gender dalam Konteks Postmemory. Poetika : Jurnal Ilmu Sastra, 4(1), 61-63. (book review). https://doi.org/10.22146/poetika.v4i1.13316 
Kumalasari, I. (2016b). The Book Thief Karya Markus Zusak: Sebuah Kajian Postmemory (Master Thesis, Universitas Gadjah Mada). Universitas Gadjah Mada, Yogyakarta. Retrieved from http://etd.repository.ugm.ac.id/penelitian/detail/94390

Laborde, C. (2019). Re/trouver sa place dans l'H/histoire: Perspectives postmémorielles dans Deuxième génération: Ce que je n'ai pas dit à mon père de Michel Kichka. French Forum, 44(1), 119-131. https://doi.org/10.1353/frf.2019.0008

Modiano, P. (1999). Dora Bruder. Paris: Editions Flammarion.

O’Byrne, C. (2019). 'To Unearth the Layers of Forgetting': Reading Boy, Lost as a Postmemoir. Life Writing, O(0), 1-13. https://doi.org/10.1080/14484528.2019.1608492

Orlando, V. K. (2016). Women, madness, myth, and film: Exploring Moroccan psychological trauma and post-memory in Pegase (Mohamed Mouftakir, 2010). The Journal of North African Studies, 21(1), 90-107. https://doi.org/10.1080/13629387.2015.1084119

Szép, E. (2014). Graphic Narratives of Women in War: Identity Construction in The Works of Zeina Abirached, Miriam Katin, and Majane Satrapi. International Studies: Interdisciplinary Political and Cultural Journal (IS), 16(1), 21-33. Retrieved from https://www.ceeol.com/search/article-detail?id=456835

Udasmoro, W. (2012). Bagaimana Meneliti Sastra: Mencermati Metodologi Dasar dalam Penelitian Sastra. Yogyakarta: Fakultas Ilmu Budaya, Universitas Gadjah Mada.

Udasmoro, W. (2014). Konstruksi Indentitas Remaja dalam Karya Sastra. Yogyakarta: Program Studi Sastra Prancis Universitas Gadjah Mada.

Udasmoro, W. (2018). Hamparan Wacana: Dari Praktik Ideologi, Media, hingga Kritik Poskolonial. Yogyakarta: Penerbit Ombak.

Wolf, D. L. (2019). Postmemories of joy? Children of Holocaust survivors and alternative family memories. Memory Studies, 12(1), 74-87. https://doi.org/10.1177/1750698018811990 
LiNGUA Vol. 16, No. 1, June 2021 • ISSN 1693-4725 • e-ISSN 2442-3823

12 | Memory Transmission in Dora Bruder Novel 